УДК $553.3 / .4$

doi 10.18522/1026-2237-2021-2-88-98

\title{
GEOCHEMICAL FEATURES OF THE DISTRIBUTION OF ORE ELEMENTS \\ IN THE POL YMETAL ORES OF MEHMANIAN DEPOSIT (AZERBAIJAN PART OF THE LESSER CAUCASUS)
}

\author{
(C) 2021 2. M.I. Mansurov ${ }^{1}$, B.H. Galandarov ${ }^{1}$, M.H. Safari', V.M. Karimov ${ }^{3}$, U.I. Karimli ${ }^{1}$ \\ ${ }^{1}$ Baku State University, Baku, Azerbaijan, \\ ${ }^{2}$ Payami Nur University, Tehran, Iran, \\ ${ }^{3}$ Azerbaijan State Oil and Industry University, Baku, Azerbaijan

\section{ГЕОХИМИЧЕСКИЕ ОСОБЕННОСТИ РАСПРОСТРАНЕНИЯ РУДНЫХ ЭЛЕМЕНТОВ В ПОЛИМЕТАЛЛИЧЕСКИХ РУДАХ МЕХМАНИНСКОГО МЕСТОРОЖДЕНИЯ (АЗЕРБАЙДЖАНСКАЯ ЧАСТЬ МАЛОГО КАВКАЗА)}

\author{
М.И. Мансуров ${ }^{1}$, Б.Г. Каландаров ${ }^{1}$, М.Г. Сафари ${ }^{2}$ В.М. Керимов ${ }^{3}$ У.И. Керимли ${ }^{1}$ \\ ${ }^{1}$ Бакинский государственный университет, Баку, Азербайджан, \\ 2 Университет Пайме Нур, Тегеран, Иран, \\ ${ }^{3}$ Азербайджанский государственный университет нефти и промышленности, Баку, Азербайджан
}

\begin{abstract}
Mamoy I. Mansurov - Associate Professor, Department of Minerals Geology, Geological Faculty, Baku State University, Z. Halilova St., 23, Baku, AZ 1148, Azerbaijan, e-mail: mamoy_mansurov@mail.ru

Bahadur H. Galandarov - Professor, Department of Minerals Geology, Geological Faculty, Baku State University, Z. Halilova St., 23, Baku, AZ 1148, Azerbaijan
\end{abstract}

Mehti H. Safari - Associate Professor, Department of Minerals Geology, Geological Faculty, Payami Nur University, Artesh St., Tehran, P.O. 19395-3697, Republic of Iran, email:mb.safari@yahoo.com

Vagif M. Karimov - Associate Professor, Department of General Geology, Geological Faculty, Azerbaijan State Oil and Industry University, Azadlig St. 20, Baku, AZ 1010, e-mail: vaqifkerimov68@mail.ru

Ulker I. Karimli - Associate Professor, Department of Minerals Geology, Geological Faculty, Baku State University, Z. Halilova St., 23, Baku, AZ 1148, Azerbaijan, e-mail: ulkerkerimli76@mail.ru
Мансуров Мамой Ибрагим огль - доцент, кафедра полезных ископаемых, геологический факультет, Бакинский государственный университет, ул. 3. Халилова, 23, г. Баку, AZ 1148, Азербайджан, e-mail: mamoy_mansurov@mail.ru

Каландаров Багадур Гасан огль - профессор, кафедра полезных ископаемых, геологический факультет, Бакинский государственный университет, ул. 3. Халилова, 23, г. Баку, AZ 1148, Азербайджан

Сафари Мехти Гаджи - доцент, кафедра полезных ископаемых, геологический факультет, Университет Пайаме Нур, ул. Артеш, г. Тегеран, П.О. 19395-3697, Республика Иран, e-mail:mb.safari@yahoo.com

Керимов Вагиф Мирзамехти огль - дочент, кафедра общей геологии, геологический факультет, Азербайджанский государственный университет нефти и промышленности, ул. Азадлыг, 20, г. Баку, AZ 1010, Азербайджан, e-mail: vaqifkerimov68@mail.ru

Керимли Улькер Ибрагим кызы - дочент, кафедра полезных ископаемых, геологический факультет, Бакинский государственный университет, ул. 3. Халилова, 23, г. Баку, AZ 1148, Азербайджан, е-mail: ulkerkerimli76@mail.ru

By using the results of geochemical research methods, the geochemical features of distribution of basic ore elements in Mehmanian polimetal deposit ores have been considered in the article. The definition features of main ore elements were given, close positive and negative relations between elements pairs were defined by correlation analysis according to the selected elements. On the basis of analysis of current analytical information results complexity has been studied, geochemical condition of localization of productive sulphide mineralization in the generation stage of ore formation has been analyzed. Behaviour features of elements have been investigated, the interaction between them has been clarified and based on their statistical analysis of geochemical features of the deposit has been made. The dependence features of one ore element from the other were determined in various types of ores of the deposit.

Keywords: Mehmana, polymetall deposits, structural-morphological, sulphide mineralization, ore elements, geochemical, correlation, statistical analysis. 
Рассмотрены геохимические особенности распространения основных рудных элементов в рудах Мехманинского полиметаллического месторождения с использованием результатов геохимических методов исследования. Дань характеристики определения основных рудных элементов, определены тесные положительные и отрицательные отношения между парами элементов путем корреляционного анализа по выбранным элементам. На основе анализа результатов аналитической данных изучена многокомпонентность полиметаллических оруденений, проанализированы геохимические условия локализации продуктивного сульфидного оруденения в стадии рудообразования. Исследованы особенности поведения элементов, выяснено взаимодействие между ними и на их основе проведен статистический анализ геохимических особенностей месторождения. Установлень особенности зависимости основных рудных элементов одного от другого в различных типах руд месторождения. Проведенное исследование имеет практическое значение для региональных и локальных прогнозно-металлогенических построений, поисков и оценки полиметаллических месторождений.

Ключевые слова: Мехмана, полиметаллические месторождения, структурно-морфологические, сульфидное оруденения, руднье элементьл, геохимический, корреляция, статистическая анализ.

\section{Introduction}

Mehmanian specific polymetal deposit is compatible to the intersection junction of Delidag-Mehmanian uplift with Agdam anticlinorium in the south-west of Lok-Agdam mature islands-arc within structurally cognominal ore field (Fig. 1). Various types of sulphide deposits are connected within ore field spacially. In one case later sulphide mineralization occurs after copper-porphyry mineralization. In the other case, forming concentration a little aside, the latter forms vein-type polymetal mineralization of industrial importance [1-3].

Within the borders of ore field, copper-porphyry, copper-polymetal, gold-pyrite and other types of deposits and occurences are conformed to exo and endocontact zones of Mekhmanian intrusive belonging to gabbro-dioritegrano-diorite formation appeared in the Upper-YurassicLower Cretaceous ages. This intrusive massif is associated with basalt-andesite-dacite formation spacially and it forms volcano-plutonic association together with it. Intrusive massif cuts through Yurassic volcanites and afterwards it is inappropriately covered with younger Cretaceous sediments (Fig. 2) [1, 4].

The main purpose of the article is to study geochemical features of copper-porphyry mineralization by analyzing petrographic-petrological features of intrusive and surrounding rocks in Mehmana ore field. The definition features of major elements and basic ore components have been investigated, their genetic and geochemical features have been studied, and the relations between pairs of the element have been defined by the correlation analysis.

\section{Research methods}

The samples of rocks were explored by the method of mass-spectroscopy with inductive-connected plasma (ICP-MS). Analytical researches were carried out in the analytical labs USGS Geological service of the USA (Denver). The composition of ore minerals was defined with the help of Camebax Inca Oxford Instruments electron-zonding microanalysers.

Petrological features of the magmatic rocks of ore district were studied by up-to-date methods. Silicate chemical analysis were carried out in the labs of the faculty of Geology of the University of Izmir, Turkey. Atom-absorption analysis in the devices (appliances) of the company Perklin Elmer allowed to define series of elements quantitatively $(\mathrm{Cu}, \mathrm{Mo}, \mathrm{Pb}, \mathrm{Zn}, \mathrm{Ni}, \mathrm{Co}, \mathrm{Sr}$, $\mathrm{Ag}, \mathrm{Cr}$ and etc.). The study of microelements were conducted in Switzerland in the devices XRF at the University of Lausanne.

The results of spectral, atomic-absorption and chemical analyzes have been used during the solution of defining the problems of basic ore components of Mekhmanian deposit polymetal ores, its genetical and geochemical features. The distribution of testing points were taken equally on the boundary of the deposit. The results of testing information were used on cropping out, both natural strip-pits, mining and drilling works were used (ditches, bore pits, wells). At the same time, the geochemical analysis of testing results has been accompanied by geological-petrographical descriptions. Analytical information is analyzed by $\mathrm{Pb}, \mathrm{Zn}$, $\mathrm{Ag}, \mathrm{Au}, \mathrm{Cu}, \mathrm{S}, \mathrm{Ni}, \mathrm{Cd}, \mathrm{In}, \mathrm{Se}, \mathrm{Mo}, \mathrm{Te}, \mathrm{Bi}$ and other elements. According to the results of surrounding rocks and mineral analysis primary materials stand on the basis of the solution of the problem. The development of statistical results of geochemical information according to the obtained results have been carried out on the programs of "STATISTICS" and "MINITAB-16".

\section{Geological setting and deposit geology}

Middle and Upper Yurassic volcanogenic rocks and sedimentary and Lower Cretaceous sedimentary and volcanogenic-sedimentary rocks participate in the geological structure of Mehmanian ore field. Fault structures play an important role in the structure of ore field. The majority of them are hidden and they have been revealed on the basis of the distantional information. 


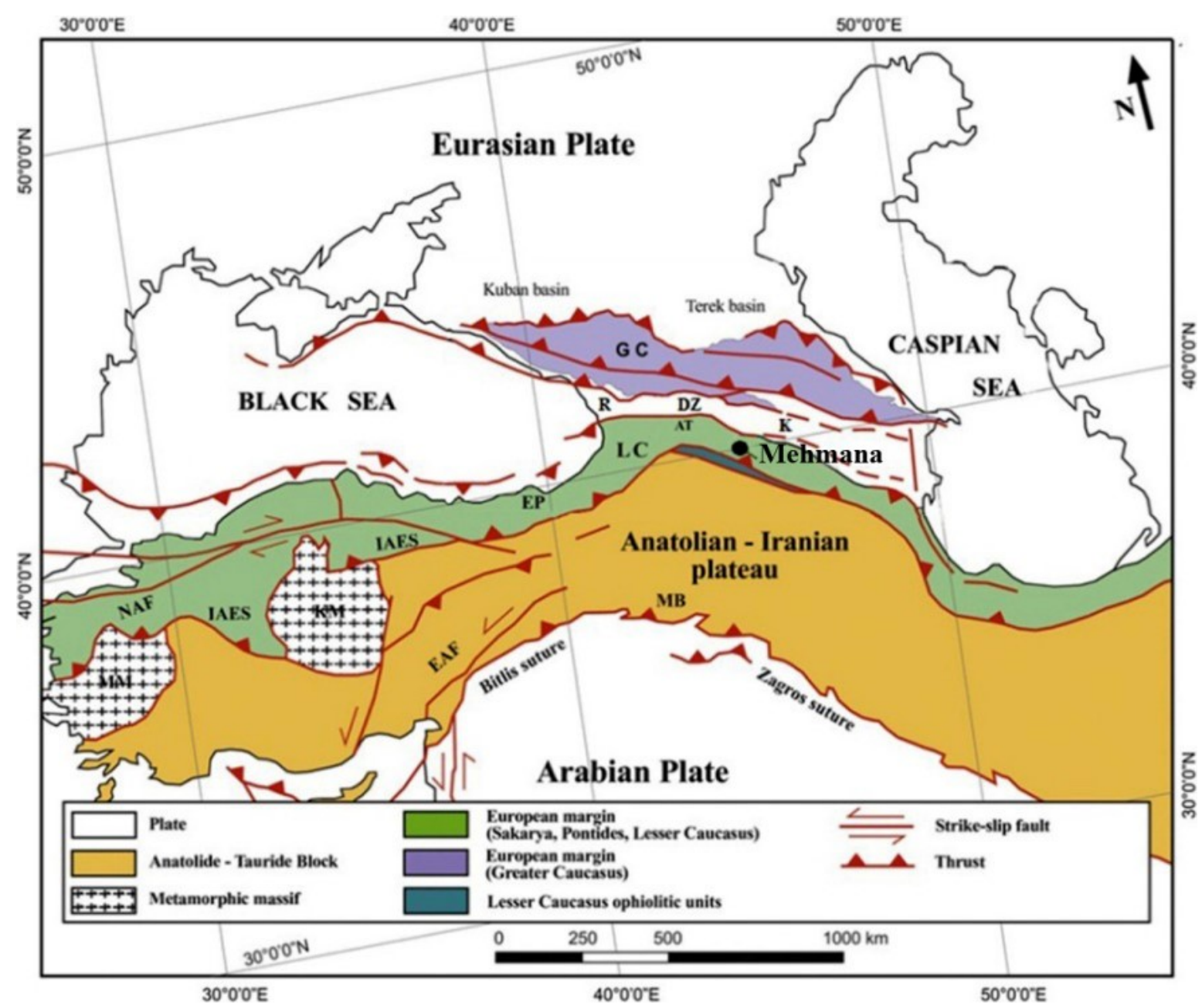

Fig. 1. Tectonic map of the Arabia-Eurasia collision zone. Location of the Mehmana deposit is shown by a filed circle (modified from Sosson et al., 2010). Abbreviations: GC - Greater Caucasus; LC - Lesser Caucasus; AT - Achara - Trialeti; R - Rioni; Dz - Dzirula; K - Kura; MB - Mus Basin; EP - Eastern Pontides; KM - Kirsehir Massif; EAF - Eastern Anatolian Fault;

NAF - North Anatolian Fault; IAES - Izmir - Ankara - Erzincan Suture; MM - Menderes Massif / Рис. 1. Тектоническая карта зоны коллизии Аравия - Евразия. Местоположение месторождения Мехмана показано кружком в поле (изменено по Sosson et al., 2010). Сокращения: GC - Большой Кавказ; LC - Малый Кавказ; AT - Аджара-Триалети; R - Риони; Dz - Дзирула;

К - Кура; МВ - Мусский бассейн; ЕР - Восточные Понтиды; КМ - массив Киршехир; ЕАF - Восточно-Анатолийский разлом; NAF - Северо-Анатолийский разлом; IAES - шов Измир-Анкара-Эрзинджан; MM - массив Мендерес

Ore controlling structures are considered striking faults in the north-west and north-east directions [5]. Gyzylbulag copper-gold-pyrite and Mehmanian specific polymetal deposit, Gulyatag and Khazindag copperpyrite manifestations, Demirli and Agdere copperporphyry deposits and occurrences and other deposits and occurrences are located along the Tartar river striking fault zone $[2,3]$.

According to A.D. Kerimov's ideas [2], the formation of Mehmanian intrusive has occurred in two phases. Massif-crystallic rocks forming the basis of intrusive massif refer to the first phase. Dyke-facies rocks and as well as a number of massifs-small intrusives were formed in the second phase. The Middle Yurassic rocks buried around the intrusive, mainly quartzitic, plagioclas- tic and other porphyrites, tuffs and tuffaceous sandstones, as well as quartz diorite-porphyrites, porphyritic banatites buried in the marginal part of the intrusive were exposed to hydrothermal-metasomatic changes to a varying degree as a result of contact activity. Such changes are represented with silicification, seritization, chloritization and limonitization. Silification covers both endocontact and exocontact rocks widely. They are turned into secondary quartzites in separate places $[3,6,7]$.

Mehmanian polimetal deposit refers to vein type for its inner structure and structural-morphological features of ore-bearing mass. All the veins lie between Batian volcanogenic and volcano-sedimentary rocks which are prone to sharp dip towards the north-west and south-east directions. 


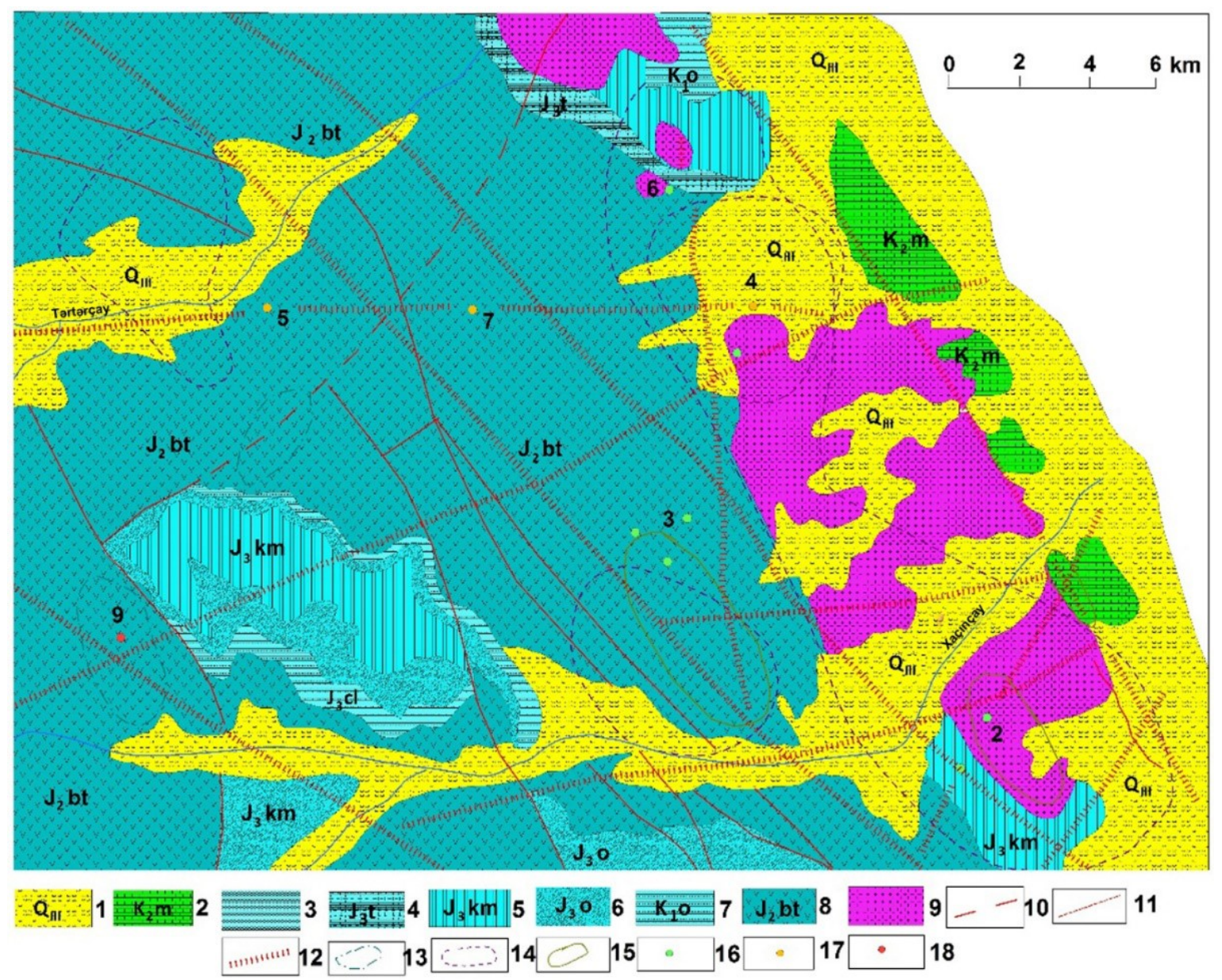

Fig. 2. Geological map of Mehmanian ore district: 1 - recent, alluvial, deluvial deposits; 2 - maastricht. Monolithic pelitomorphic limestones; 3 - albanian. Tuff sandstones, tuff breccia, marl; 4 - tithonian. Fragmental limestones; 5 - kimmeridgian. Tuff conglomerates, tuff breccias, tuff gravelstones; 6 - oxfordian. Fragmental-sandy limestones; 7 - callovian. Tuff sandstones, tuff gravelsotnes; 8 - bathonian. Tuff conglomerates, tuff sandstones, tuff breccias, porphyrites, quartz porphyrites; 9 - granodiorites, granodiorite-porphyres. Tectonic faults; 10 - known faults; 11 - assumed faults; 12 - faults marked according to complex of distance data (geophysical, aerospace). Anomalous areas: 13 - on CP; 14 - on positive anomalies of magnetic field which correspond to buried intrusive bodies of medium composi-

tion; 15 - areas with multiplicative geochemical anomalies on the secondary aureole: $\mathrm{Cu} \times \mathrm{Mo} \times \mathrm{Ag}++\mathrm{Pb}+\mathrm{Zn}+\mathrm{Co}$ (more than $500 \cdot 10^{-11} \%$ on background of $50 \cdot 10^{-11} \%$ ). Deposits and occurrences: 16 - porphyry copper (1 - Demirli; 2 - Khachinchai; 3 - Kazanchin; 6 - Agdere); 17 - complex ores (4 - Gulyatag; 5 - Gyzylbulag; 7 - Mekhmanian); 18 - copper-sulphide (8 - Khazinadag) / Рис. 2. Геологическая карта Мехманинского рудного района: 1 - современные, алювиальные, делювиальные отложения; 2 - маастрихт. Монолитные пелитоморфные известняки; 3 - альб. Туфопесчаники, туфобрекчии, мергели; 4 - титон. Обломочные известняки; 5 - кимеридж. Туфоконгломераты, туфобрекчии, туфогравелиты; 6 - оксфорд. Обломочно-песчанистые известняки; 7 - келловей. Туфопесчаники, туфогравелиты; 8 - бат. Туфоконгломераты, туфопесчаники, туфобрекчии, порфириты, кварцевые порфириты; 9 - гранодиориты, гранодиорит-порфиры. Тектонические нарушения; 10 - достоверные разломы; 11 - предполагаемые разломы; 12 - разломы, выделенные по комплексу дистанционных данных (геофизических, аэрокосмических). Аномальные участки: 13 - по ВП (Чк $\geq 4,0$ \% при фоне 2,0 \%); 14 - по положительным аномалиям магнитного поля, соответствующим скрытым интрузивным телам среднего состава; 15 - участки мультипликативных геохимических аномалий по вторичным ореолам: $\mathrm{Cu} \times \mathrm{Mo} \times \mathrm{Ag}+\mathrm{Pb}+\mathrm{Zn}+\mathrm{Co}$ (более $500 \cdot 10^{-11} \%$ на фоне 50·10-11 \%). Месторождения и проявления: 16 - медно-порфировые

(1 - Демирлинское; 2 - Хачинчайское; 3 - Казанчинское; 6 - Агдаринское); 17 - комплексных руд (4 - Гюльятагское; 5 - Гызылбулагское; 7 - Мехманинское); 18 - медноколчеданные (8 - Хазинадагское)

The thickness and shape of ore veins depend on the lithological composition of the surrounding rocks and it's observed along the whole deposit area. During the intensive hydrothermal change of rocks the selvage of veins is not observed clearly. The total amount of detected veins is nearly 30 and the majority of them are localized in the fault structures in the direction close to width $[2,3,8]$.

Though zonality is observed in separate veins, stable vertical zonality hasn't been defined here. The definition of ore elements along strikings and dippings is inequal in the veins, the shift of intervals of industrial 
importance and without ore is observed in all of them. The amount of turbid ores in the tongues increases in the western end of vein and they are considered basic ore-forming minerals together with sphalerite. Quartzgalenite-sphalerite mineral association widely developed in the deposit and galenite prevails over sphalerite in quantity [9-11].

Different minerals participate in the composition of lead-zink ores of the deposit. Galenite, sphalerite, chalcopyrite and pyrite are referred to primary ore minerals. The amount of $\mathrm{Pb}$ comprises $50 \%$ in galenite, but the amount of zink comprises $42 \%$ in sphalerite [9]. Galenite veinlets form bunches and phenocrysts, as well as fine-grained veinlet-like and lens-like mass. Sphalerite mineralization has widely spread mainly in the eastern part of the deposit and they usually form bunches, lens-like mass and veinlets [2,9].

$\mathrm{Pb}, \mathrm{Zn}, \mathrm{Ag}, \mathrm{Au}, \mathrm{Cu}, \mathrm{S}, \mathrm{Ni}, \mathrm{Cd}, \mathrm{In}, \mathrm{Se}, \mathrm{Mo}, \mathrm{Te}, \mathrm{Bi}$ and other elements participate in the content of polimetal ores. We should mention that, $\mathrm{Au}$ and $\mathrm{Ag}$ are found in many ore veins. Certain compliance is observed in definition of their amount. According to N.R. Ilyasov [12], the amount of $\mathrm{Au}$ is low in galenite and sphalerite and doesn't participate in their composition (it is absent in their composition) [13].

The high amount of Au is observed in the ore veins where the quantity of chalcopyrite is much. Free Au was defined in chalcopyrite-pyrite, sphaleritechalcopyrite, specific sphalerite, magnetite-sulphide ores. It indicates that free Au participates in all stages of mineralization. In the sphalerite ores, the separation of $\mathrm{Au}$ is observed in the sphalerite, galenite and quartz, but in the magnetite-sulphide ore free gold is found in chalcopyrite and bornite. More correctly, paragenetic relations of this mineral with ore minerals is observed. For this reason, maximum amount of $\mathrm{Au}$ is compatible to the maximum concentration of copper ore. Paragenetic relations of $\mathrm{Au}$ with chalcopyrite and sphalerite indicates that they are found in the areas where these minerals prevail most [14-16].

The high amount of $\mathrm{Ag}$ is observed in the area where galenite develops much (Table 1).

Table 1

The amount of Ag of Mehmanian deposit in galenite ores

/ Содержание Ag в галенитовых рудах Мехманинского месторождения

\begin{tabular}{|c|c|c|}
\hline Veins & $\begin{array}{c}\text { Absolute altitude } \\
\text { where the experiment } \\
\text { was done (with meters) }\end{array}$ & $\begin{array}{c}\text { Average amount } \\
\text { of Ag /q/t }\end{array}$ \\
\hline Lead-Sacher & 838 & 63.3 \\
Lead-Sacher & 972 & 71.4 \\
"B" & 1017 & 154.0 \\
Spridonov & 1119 & 219.6 \\
\hline
\end{tabular}

But, free $\mathrm{Ag}$ is found in copper-pyrite and specific sphalerite ores. A number of researchers associate the formation of free Ag with re-enrichment sulphide zone of ores [10].

The amount of $\mathrm{Ag}$ in pyrite chalcopyrite ores changes till $203 \mathrm{q} / \mathrm{t}$. At the same time, its small concentration can be found in massive ores. The amount of $\mathrm{Ag}$ varies between $0.5-29.4 \mathrm{q} / \mathrm{t}$ intervals in chalcopyrite-sphalerite ores. Greater (higher) amount of $\mathrm{Ag}$ is observed in sphalerite and sphalerite-galenite ores in the eastern flang of the deposit. High amount of $\mathrm{Ag}$ is characteristic for other sphalerite veins. The amount of $\mathrm{Ag}$ in sphalerite-galenite veins is higher than specific sphalerite ores $[9,10,12]$.

$\mathrm{Au}$ and $\mathrm{Ag}$ are found in most ore veins of Mehmanian deposit and their definition is inequal in the ores. The amount of $\mathrm{Au}$ is low in galenite and galenite-sphalerite mineral associations, sometimes it is not even found. High concentration of $\mathrm{Au}$ is connected with the areas where pyrite-chalcopyrite prevail $[10,17]$.

According to V.M. Babazade [18], Ag-Au proportion has non-linear feature. The lowest proportion (3.0:3.6 q/t) is observed in pyrite-chalcopyrite and chalcopyrite-sphalerite mineral associations, but high proportion can be found in sphalerite and sphaleritegalenite ores (21.0-110 q/t). Ag:Au proportion makes special interest and depending on the mineral composition of ores it changes towards bedding depth (depth of dip) (Table 2).

Table 2

Ag:Au proportion in Mehmanian deposit ores / Соотношения Ag:Au в рудах Мехманинского месторождения

\begin{tabular}{|l|c|}
\hline \multicolumn{1}{|c|}{ Type of ore } & $\mathrm{Ag}: \mathrm{Au}$ \\
\hline Pyrite-chalcopyrite & 3.6 \\
\hline Chalcopyrite sphalerite & 3.0 \\
\hline Sphalerite & 21.0 \\
\hline Sphalerite-galenite & 110.0 \\
\hline
\end{tabular}

$\mathrm{Au}$ has been found in pyrite-chalcopyrite, sphaleritechalcopyrite, specific sphalerite and magnetite-sulphide type ores. It indicates that, $\mathrm{Au}$ has participated in all mineral forming stages. Its close paragenetic relations with copper minerals are observed. The positive correlation relations between $\mathrm{Au}$ and $\mathrm{Cu}$ confirms it $\left(\mathrm{r}_{\mathrm{Au}-}\right.$ $\mathrm{Cu}=0.46$ ). In this case, it has negative correlation relations with $\mathrm{Pb}\left(\mathrm{r}_{\mathrm{Au}-\mathrm{Pb}}=0.75\right), \mathrm{Zn}\left(\mathrm{r}_{\mathrm{Au}-\mathrm{Ag}}=0.67\right)$ and also $\mathrm{Ag}$ $\left(\mathrm{r}_{\mathrm{Au}-\mathrm{Ag}}=0.83\right)$. The obtained information shows once again that high amount of $\mathrm{Au}$ is compatible to maximum concentration field of copper ores (Table 3) $[10,18]$.

The dependence of $\mathrm{Cd}$ is observed in sphalerite. It likely takes part in a form of isomorphic mixture here. The results of chemical analysis of various generation of sphalerite shows high amount of Cd: sphalerite I marmatite type $0.34 \%$, sphalerite II $0.21 \%$. Cd is found in pyrite (till $210 \mathrm{q} / \mathrm{t}$ ), in chalcopyrite (until 
$350 \mathrm{q} / \mathrm{t}$ ) and in galenite (till $220 \mathrm{q} / \mathrm{t}$ ) [10]. It is found in sulphides, especially in sphalerite (till $2010 \mathrm{q} / \mathrm{t}$ ). Sphalerite is considered main concentrate for it. According to Galandarov [10], on the analysis results of basic ore minerals (galenite, sphalerite, chalcopyrite, pyrite), major sulphide minerals are considered chalcopyrite (up to $460 \mathrm{q} / \mathrm{t}$ ) and sphalerite (up to $340 \mathrm{q} / \mathrm{t}$ ). The amount of Se and $\mathrm{Te}$ is in insignificant quantity in lead-zink ores and their definition is inequal. Relatively high amount of $\mathrm{Bi}$ was revealed in galenite (1.0$53.0 \mathrm{q} / \mathrm{t})[19]$.

Table 3

Correlation of the main and adjacent elements of the ore bed / Корреляционная связь основных и сопутствующих элементов руд Мехманинского месторождения

\begin{tabular}{|l|c|c|c|c|}
\hline \multicolumn{1}{|c|}{ Elements } & $\mathrm{Zn}$ & $\mathrm{Cu}$ & $\mathrm{Au}$ & $\mathrm{Ag}$ \\
\hline $\mathrm{Pb}$ & 0.05 & -0.38 & -0.75 & 1.0 \\
\hline $\mathrm{Zn}$ & & -0.40 & -0.67 & 0.42 \\
\hline $\mathrm{Cu}$ & & & 0.46 & -0.60 \\
\hline $\mathrm{Au}$ & & & & -0.83 \\
\hline
\end{tabular}

High amount of $\mathrm{Ag}$ is compatible to the area where galenite is accumulated. It is found among galenite veins comprising the association with non-ore minerals in a form of veinlets and bunches here.

According to [14] ideas, only a small part of silver preserved in polymetal ores of Mehmanian deposit is associated with native silver. Its significant distribution is connected with galenite and galenite-sphalerite mineralization.
According to Ilyasov [12], higher concentration of $\mathrm{Ag}$ belongs to sphalerite and sphalerite-galenite ores. The amount of $\mathrm{Ag}$ is higher in galenite in comparison with sphalerite $(1.8-22.1 \mathrm{q} / \mathrm{t}$, average $13.1 \mathrm{q} / \mathrm{t}$ in sphalerite-galenite veins). According to the mentioned factors, we can come to such a conclusion that, basic carriers of $\mathrm{Ag}$ are galenite and sphalerite in the polymetal ores of Mehmanian deposit. At the same time, the amount of Ag in the upper ore-carrier horizon in galenite is relatively higher than lower horizon (Table 4).

Table 4

Change of the amount of $\mathrm{Ag}$ in galenite according to vertical section in Mehmanian deposit / Изменения содержания Ag в галенитах Мехманинского месторождения по вертикали

\begin{tabular}{|l|c|c|}
\hline \multirow{2}{*}{ Altitude } & \multicolumn{2}{|c|}{ Quantity, q/t } \\
\cline { 2 - 3 } & Limit of quantity & Average \\
\hline Up to $900 \mathrm{~m}$ & $63.3-71.4$ & 67.35 \\
$900-1100 \mathrm{~m}$ & $71.4-219.6$ & 148.13 \\
$1100-1130 \mathrm{~m}$ & $154.0-219.6$ & 181.67 \\
\hline
\end{tabular}

Average quantity of the elements such as $\mathrm{Au}, \mathrm{Ag}$, $\mathrm{Cu}, \mathrm{Zn}$ and $\mathrm{Pb}$ was given in the Table 5 in various ore veins according to the Mehmanian deposit. On the basis of this information, linear dependence graphics and definition histograms of basic ore elements have been set up in various types of ore. The operation was carried out by "MINITAB-16" computer program.

Average quantity of $\mathrm{Au}, \mathrm{Ag}, \mathrm{Pb}, \mathrm{Zn}$ and $\mathrm{Cu}$ in various types of ores of the Mehmanian deposit / Среднее содержание $\mathrm{Au}, \mathrm{Ag}, \mathrm{Pb}, \mathrm{Zn}$ и Сu в различных типах рудах Мехманинского месторождения

\begin{tabular}{|c|c|c|c|c|c|}
\hline The place where & $\mathrm{Au}, \mathrm{q} / \mathrm{t}$ & $\mathrm{Ag}, \mathrm{q} / \mathrm{t}$ & $\mathrm{Cu}, \%$ & $\mathrm{Zn}, \%$ & $\mathrm{~Pb}, \%$ \\
\hline Erchin-guney & 10.6 & 29.1 & 3.7 & 1.37 & - \\
\hline Dana-guney & 2.2 & - & 1.7 & 4.5 & 1.43 \\
\hline Erkatzor & 2.2 & - & 1.74 & - & 0.02 \\
\hline $\begin{array}{l}\text { Sedimentary (according } \\
\text { to information on cave) }\end{array}$ & 8.1 & - & 2.75 & 1.31 & - \\
\hline $\begin{array}{l}\text { Sedimentary (according } \\
\text { to surface mountain hole) }\end{array}$ & 0.6 & - & 0.15 & 0.02 & - \\
\hline Vein 1-9 & 3.6 & - & 2.4 & 0.05 & 0.01 \\
\hline Vein No. 6 & 2.0 & - & 1.1 & 0.71 & 0.09 \\
\hline Vein No. 6a & 0.5 & - & 0.11 & 0.25 & 0.02 \\
\hline Vein No. 7 & 0.7 & - & 0.36 & 1.08 & 0.03 \\
\hline Vein No. 5 & 8.4 & - & 1.72 & 1.92 & 0.02 \\
\hline Vein No.4 & 10.9 & 9.0 & 1.24 & 0.4 & 0.1 \\
\hline Venindere & 1.0 & - & 1.0 & 2.73 & 0.2 \\
\hline Dmitriyev & 1.5 & 29.4 & 0.05 & 16.7 & 0.76 \\
\hline Spridonov & 0.5 & 32.3 & 0.06 & 3.79 & 3.67 \\
\hline Old-Monastr & 0.4 & 14.1 & 0.08 & 7.79 & 0.17 \\
\hline Vein No. 1 & 1.3 & - & 0.03 & 5.23 & 0.34 \\
\hline Vein No. 2 & 0.6 & 6.9 & 0.3 & 7.44 & 0.33 \\
\hline Akritov & 0.6 & 52.5 & 0.21 & 8.6 & 1.94 \\
\hline Lead-Sacher & 0.1 & 17.2 & 0.01 & 2.26 & 5.94 \\
\hline "B" & 0.7 & 74.0 & 0.09 & 2.66 & 8.37 \\
\hline Western Drombon & - & 26.1 & 0.12 & 2.19 & 1.12 \\
\hline
\end{tabular}


Basic ore-forming sulphides-galenite and sphalerite are characterized by low quantity of absence of gold, but chalcopyrite is characterized by considerable amount of gold. Straight correlation relations has been defined between concentration of gold and intensivity of manifestation of mineralization of chalcopyrite. Unlike gold, high concentration of gold is observed in the ore-bearing fields which preserve maximum amount of galenite and galenite-sphalerite mineralization $[10,17,20]$.

\section{Discussions}

For the solution of the issue, behavior features of chemical elements in the ores were investigated and a few point dependence graphics reflecting dependence relations between the elements were set up. In order to study the definition features of indicator elements, interactions between them were investigated and on the basis of them, statistical analysis of geochemical features of the deposit were made.

As seen from the analysis, dependence of pairs of the element is symmetrically repeated relatively to diagonal. Dependent variabilities were shown in the vertical axis of graphics, but independent variabilities (changers) were indicated in the horizontal axis of graphics.

Dependence features of one basic ore element of the deposit from the other are analyzed below. First, dependence relations of $\mathrm{Pb}$ and $\mathrm{Zn}$ elements from $\mathrm{Cu}, \mathrm{Ag}$, $\mathrm{Au}$ elements and at the same time dependence relations of these elements between themselves have been given. As seen from the diagram, main part of point clouds was accumulated around regression line, in the initial line, but small part of it in the margin of the line. In the dependence diagram of $\mathrm{Pb}$ and $\mathrm{Zn}$ with $\mathrm{Ag}$, point clouds were accumulated along the vertical line. It is noticed in the diagonals that, there is significantly close correlation relation between these elements (Fig. 3). The distribution of points around straight regression line is more, but correlation coefficient is relatively low here.

The dependence graphics of the amount of $\mathrm{Cu}, \mathrm{Au}$ and $\mathrm{Ag}$ from the amount of $\mathrm{Pb}$ and $\mathrm{Zn}$ are shown in the Fig. 4. At the same time, dependence graphics of these elements between themselves is shown too. Here the distribution of points are not compatible to regression line. So, the distribution of points is inequal in the right half of straight regression curve. But, here regression curve must in- crease relatively to the current situation. Clouds of point were accumulated mainly along the regression line, particularly in the initial line with the exception of $\mathrm{Cu}-\mathrm{Ag}$ dependence, in the dependence diagram of $\mathrm{Cu}$ from other elements [21]. The ores containing great amount of $\mathrm{Cu}$ and small amount of $\mathrm{Zn}$ are referred to oxides and they are localized near the upper part of ore mass where $\mathrm{Cu}$ is found [22].

In the dependence diagram of $\mathrm{Au}$ with other elements the situation is quite different in comparison with the others. So, there is incompatibility in the distribution of points here, clouds of point have been straightened according to the vertical section, not along the regression line.
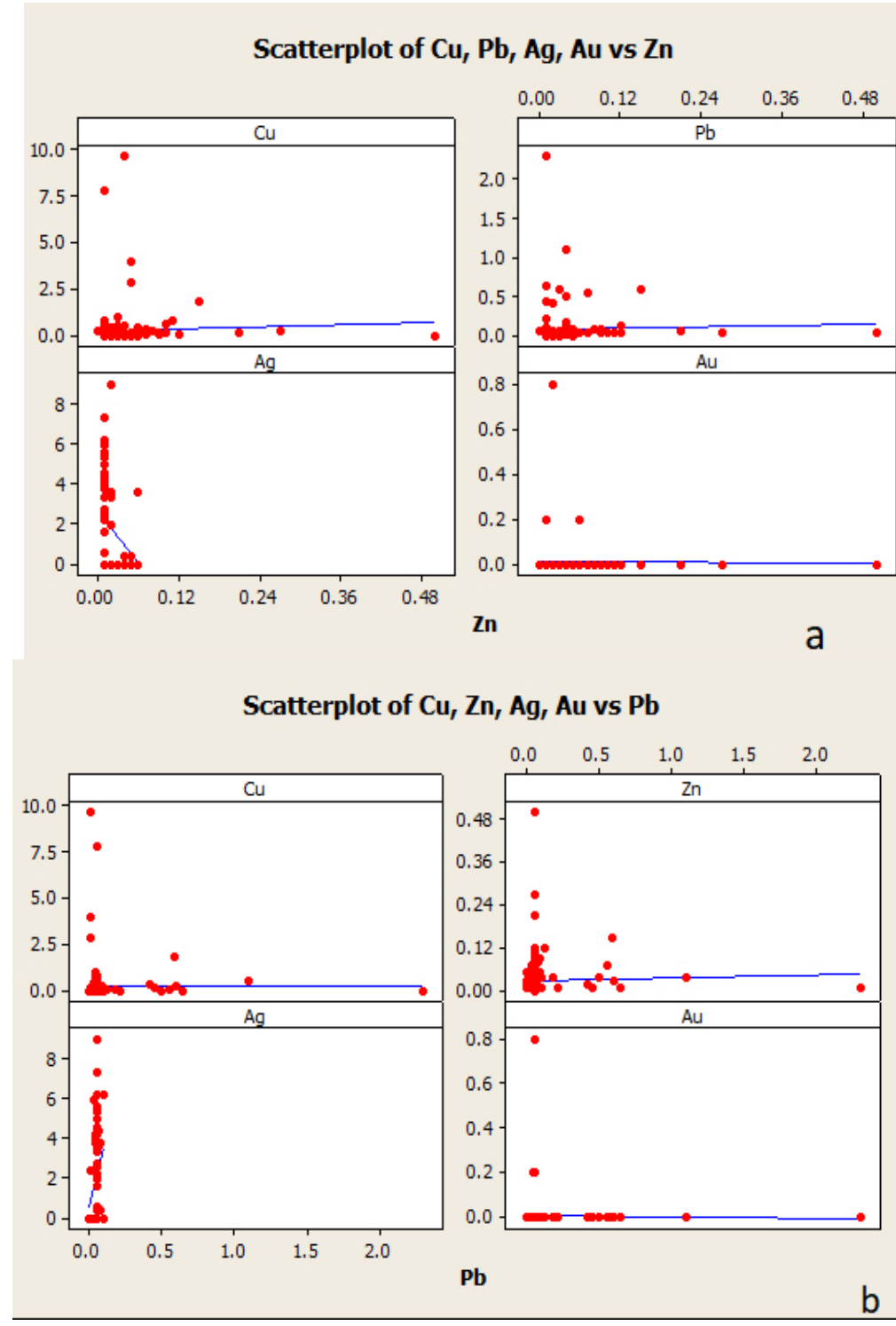

Fig. 3. Linear dependence graphics of $\mathrm{Zn}(\mathrm{a})$ and $\mathrm{Pb}(\mathrm{b})$ with other ore elements in various types of ores in the Mehmanian deposit / Рис. 3. Графики линейных зависимостей $\mathrm{Zn}(\mathrm{a})$ и $\mathrm{Pb}(\mathrm{b})$ с другими рудными элементами в различных типах руд Мехманинского месторождения 
In the point dependence diagram between $\mathrm{Ag}$ and $\mathrm{Zn}, \mathrm{Pb}, \mathrm{Cu}$ and $\mathrm{Au}$ clouds of point are distributed in the margins and along the regression line equally.

In the other case, incompatibility is observed between the distribution of points and regression line in the dependence diagram between $\mathrm{Ag}$ and $\mathrm{Zn}$ and $\mathrm{Pb}$ like the previous diagram (Fig. 4). Two accumulation areas of point clouds are separated in each of these diagrams. Basic accumulation area of points is compatible to primary sulphide ores. One of the other two areas reflecting small amount of point is characterized by anomalous amount of $\mathrm{Pb}$, the other is characterized by $\mathrm{Zn}$. These two point clouds reflecting anomalous amount of $\mathrm{Zn}$ and $\mathrm{Pb}$ respond to oxide ores of the deposit.

As seen from the analysis of diagrams, the more the number of samples is, he more closely these points will be grouped. More portable collection of points respond to the samples obtained from the primary sulphides of the deposit. Collections of point extended along the vertical axis of the left side of diagram are likely production of oxide ores. According to the analysis of linear dependence diagrams between basic components $(\mathrm{Pb}, \mathrm{Zn}, \mathrm{Cu} \mathrm{Ag}, \mathrm{Au})$ in various types of ores on the Mehmanian deposit, we can note that the definition of majority of the shown chemical elements are due to positive correlation relations. It shows that all these emerged as a result of single geochemical processes. All studied samples are not homogenous and at least three mineral associations participate in polymetal ore mass: 1) primary sulphide ores; 2) oxide ores; 3) significantly enriched sulphide ores with $\mathrm{Pb}[20,22]$.

Along with linear dependence between basic ore elements $(\mathrm{Pb}, \mathrm{Zn}, \mathrm{Cu}, \mathrm{Ag}, \mathrm{Au})$ definition features of these elements have been considered, too. On this purpose, definition histograms of these elements were set up. As seen from these histograms, the results of samples obtained from aureoles of this deposit and mineralized rocks are reflected here. This combined feature has been reflected in the structure of histograms. More portable, symmetric and the same peaked form appeared here in the histograms set for $\mathrm{Au}$ and $\mathrm{Pb}$, partially $\mathrm{Cu}$. Normal definition curves of elements are described here well (Fig. 5).
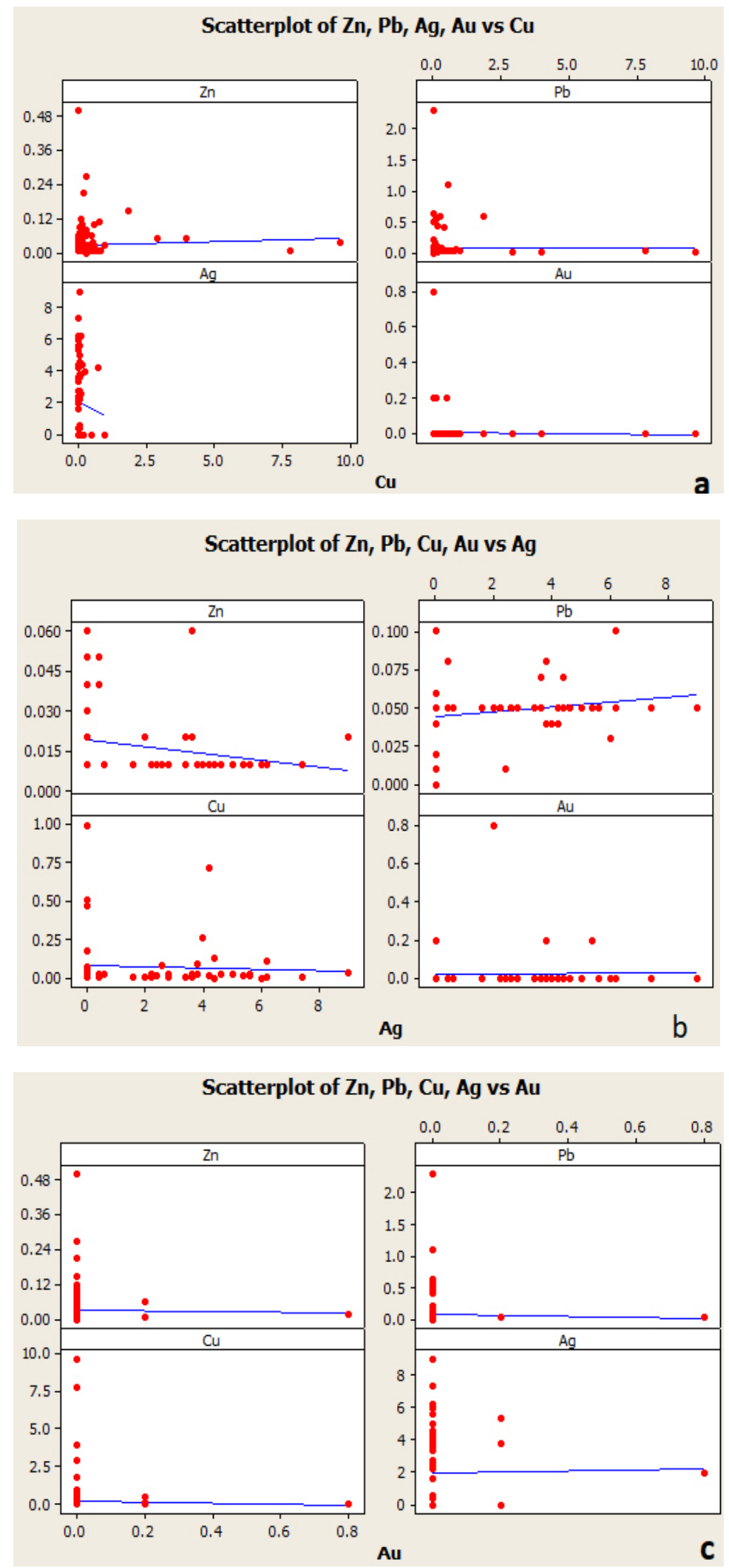

Fig. 4. Linear dependence graphics of $\mathrm{Cu}(\mathrm{a}), \mathrm{Au}(\mathrm{b})$ and $\mathrm{Ag}(\mathrm{c})$ with ore elements in various types of ores of the Mehmanian deposit / Рис. 4. Графики линейных зависимостей $\mathrm{Cu}(\mathrm{a}), \mathrm{Au}(\mathrm{b})$ и $\mathrm{Ag}(\mathrm{c})$ с другими рудными элементами в различных типах руд Мехманинского месторождения 

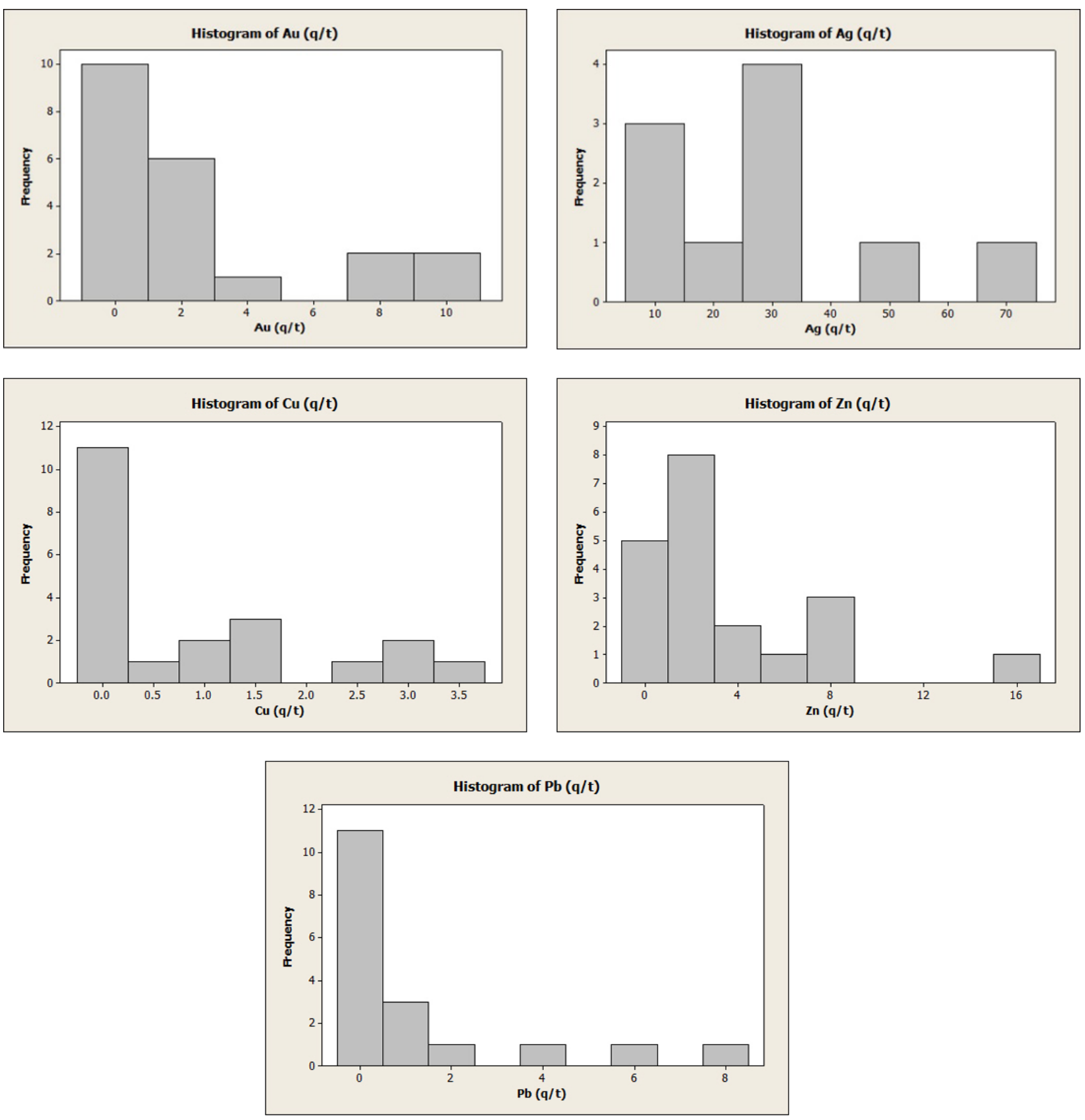

Fig. 5. Definition histograms of basic ore elements in Mehmanian polymetal deposit

/ Рис. 5. Гистограммы определения основных рудных элементов Мехманинского полиметаллического месторождения

This symmetry was broken in the histograms compiled for Ag and $\mathrm{Zn}$. Definition curves are different and they possess abnormal feature.

We can come to such a conclusion that the totality of all samples reflect two definition combinations of basic ore components in itself: normal identification in the ore mass of the deposit and abnormal identification in the aureole part.

\section{Conclusion}

1. Major components in the ores $(\mathrm{Pb}, \mathrm{Zn}, \mathrm{Au}, \mathrm{Ag}$, $\mathrm{Cu}, \mathrm{Cd}, \mathrm{In}, \mathrm{Bi}$ and etc.), basic concentrates are considered sulphide minerals: sphalerite, galenite, chalcopyrite and pyrite. Certain legitimacy is observed in their identification, significant close positive correlation relations are noticed between them. 
2. Proportions of amount of $\mathrm{Pb}$ and $\mathrm{Zn}$ changes differently in various spheres of deposit and it's connected with the variety of migration features of those elements during geochemical processes.

3. The analysis of mineralogical-geochemical features of polymetal mineralization of the deposit shows that basic carriers of $\mathrm{Ag}$ are galenite and sphalerite in the ores. The amount of $\mathrm{Ag}$ in galenite in the upper ore-carrying horizons are higher than in lower horizons.

4. Au participated in all mineral-forming stages (pyrite-chalcopyrite, sphalerite-chalcopyrite, magnetite-sulphide) and its high amount correspond to maximum concentration field of $\mathrm{Cu}$ mineralization.

5. The availability of close correlation relations between $\mathrm{Pb}, \mathrm{Zn}, \mathrm{Cu}, \mathrm{Au}$ and $\mathrm{Ag}$ gives us basis to think that they are the products of single geochemical processes.

6. Sphalerite and sphalerite-galenite ores in specific lead-zink ore mass are of great importance and the conduction of complex investigation work is recommended by applying mineralogical geochemical methods for revealing new ore mass in northern and northeastern flanks.

\section{References}

1. Kerimov A.D. (1965). Petrology and mineralization of the Mehmanian granitoid intrusive. Baku, Azerbaijan Academy of Sciences Press, 165 p. (in Russian).

2. Geology of Azerbaijan. Useful Minerals. (2006). Baku, Nafta-Press, vol. 5, 574 p. (in Russian).

3. Mineral-Raw Resources of Azerbaijan (conditions of formation, patterns of placement, scientific foundations of forecasting). (2005). V.M. Baba-zade (Ed.). Baku, Ozan Publ., 808 p. (in Russian).

4. Geology of Azerbaijan. Tectonics. (2005). Baku, Nafta-Press, vol. 4, 505 p. (in Russian).

5. Geology of Azerbaijan. Magmatism. (2001). Baku, Nafta-Press, vol. 3, 524 p. (in Russian).

6. Mansurov M.I., Kalandarov B.G., Safarov E.I. (2017). Geological-genetical features and conditions of localization of the ores of copper-porphyry deposits of Mehmanian ore district (Azerbaijanian part of Lesser Caucasus). Ural Geological Journal, No. 6, pp. 48-57. (in Russian).

7. Mansurov M.I. (2013). Factors of localization of copper-polymetallic mineralization of the Elbekdash deposit (Small Caucasus, Azerbaijan). Bulletin of the Baku University. Natural Sciences Series, No. 1, pp. 99-109. (in Russian).

8. Zaytseva L.V, Rafibeyli P. Kh. (1964). Structural features of Mehmanian ore field and stage of mineralization. Conformity of distribution of useful minerals. Moscow, Nauka Publ., vol. 7, pp. 64-79. (in Russian).
9. Khalilova T.A. (1972). Mineralogy of Mehmanian group of pig-zinc sites. Baku, Elm Publ., 72 p. (in Russian).

10. Kalandarov B.G. (2010). Polymetallic ore formation of the Lesser Caucasus. Dissertation Thesis. Baku, 50 p. (in Russian).

11. Naumov N.B., Girnis A.V., Dorofeyeva V.A., Kovalenker V.A. (2016). Concentration of ore elements and in magmatic melt and natural fluids according to the concerned study of the inclusions in minerals. Geology of Ore Deposits, vol. 58 (4), pp. 367-384. (in Russian).

12. Ilyasov N.R. (1974). Geochemistry of gold and silver in the deposits and in one of ore fields of the Lesser Caucasus. Dissertation Thesis. Baku, 38 p. (in Russian).

13. Chan Tuan Ann, Gaskov I.V., Chan Chong Hoa, Nevalko P.A., Fam Tkhi Zung (2012). Mineralogicalgeochemical features and conditions of the formation of polymetallic deposits of the structure of Logam, NorthEastern Vietnam. Geology and Geophysics, vol. 55 (7), pp. 817-833. (in Russian).

14. Heydarov A.S., Efendiyev G.Kh., Lajinina N.F. (1966). Rare elements of the ores of Mehmanian group of polymetallic deposits. Geochemistry of rare elements. Baku, Azerbaijan Academy of Sciences Press, pp. 27-38. (in Russian).

15. Kovalev K.R., Distanov E.G., Anoshin G.N., Gaskov I.V., Akimtsev V.A., Baulina M.V. (2004). Gold and silver in the ores of volcanogenic hydrothermal and hydrothermal-sedimentary pyrite-polymetallic deposits of Siberia. Geology and Geophysics, vol. 45 (10), pp. 11711185. (in Russian).

16. Volkov A.V., Saava P.E., Kolova E.E., Prokofev V.Yu., Murashov K.Yu. (2018). Au-Ag epithermal deposits of double deposits (Chukotka, Russia). Geology of Ore Deposits, vol. 60 (6), pp. 596-609. (in Russian).

17. Mansurov M.I., Kalandarov B.G., Karimli U.I., Huseynov A.I. (2020). Distribution of gold and associated ore-bearing elements in gold-copper-pyrite ores of the Kyzybulag deposit (Lesser Caucasus, Azerbaijan). Bulletin of Higher Educational Institutions. North Caucasus Region. Natural Science, No. 3 (207), pp. 51-59. Doi 10.18522/1026-2237-2020-3. (in Russian).

18. Baba-zade V.M., Bektashi S.A., Kalandarov B.G. (1995). Silver containing polymetallic ore of Azerbaijan part of the Lesser Caucasus. News of Baku University. Series of Natural sciences, No. 2, pp. 86-93. (in Russian).

19. Gaskov I.V., Vladimirov A.G., Khanchuk A.I., Pavlova G.A., Gvozdev V.I. (2017). Peculiarities of distribution of indium in the ores of several polymetallic and tin-sulphide deposit of Siberia and Far East of Russia. Geology of Ore Deposits, No. 1, pp. 62-74. (in Russian).

20. Geochemistry of process of migration of ore elements. (1977). N.I. Khitarov (Ed.). Moscow, Nauka Publ., 70 p. (in Russian).

21. Danilchenko V.A., Vargunina N.P., Gordeyev S.G., Orlov B.Yu. (2004). Hidden lead-zinc mineralization within the boundaries of region of Gaudor, Sadonsky 
ore district. Geology and Exploration, No. 1, pp. 37-42. (in Russian).

22. Dobrovolskaya M.G. (1989). Lead-zinc mineralization (ore formation, mineral paragenesis, features of mineralization). Moscow, Nauka Publ., 216 p. (in Russian).

\section{Литература}

1. Керимов А.Д. Петрология и рудоносность Мехманинского гранитоидного интрузива. Баку: АН Азерб. ССР, 1965. 165 с.

2. Геология Азербайджана. Полезные ископаемые. Баку: Nafta-Press, 2006. T. V. 574 с.

3. Минерально-сырьевые ресурсы Азербайджана (условия формирования, закономерности размещения, научные основы прогнозирования) / под. ред. проф. В.М. Баба-заде. Баку: Озан, 2005. 808 с.

4. Геология Азербайджана. Тектоника. Баку: Nafta-Press, 2005. T. IV. 505 c.

5. Геология Азербайджана. Магматизм. Баку: Nafta-Press, 2003. T. III. 524 c.

6. Мансуров М.И., Каландаров Б.Г., Сафаров Э.И. Геолого-генетические особенности и условия локализации руд медно-порфировых месторождений Мехманинского рудного района (азербайджанская часть Малого Кавказа) // Уральский геол. журн. 2017. № 6. C. $48-57$.

7. Мансуров М.И. Факторы локализации меднополиметаллического оруденения Элбекдашского месторождения (Малый Кавказ, Азербайджан) // Вестн. Бакинского ун-та. Серия естественных наук. 2013. № 1. С. 99-109.

8. Зайцева Л.В., Рафибейли Р.Х. Структурные особенности Мехманинского рудного поля и стадийность рудообразования // Закономерности размещения полезных ископаемых. М.: Наука, 1964. Т. 7. С. 64-79.

9. Халилова Т.A. Минералогия Мехманинской группы свинцово-цинковых месторождений. Баку: Элм, $1972.76 \mathrm{c.}$

10.Каландаров Б.Г. Полиметаллические рудные формации Малого Кавказа : автореф. дис. ... д-ра геол.-мин. наук. Баку, 2010. 49 с.

11. Наумов Н.Б., Гирнис А.В., Дорофеева В.А., Коваленкер B.A. Концентрация рудных элементов в магматических расплавах и природных флюидах по данным изучения включений в минералах // Геология рудных месторождений. 2016. Т. 58, № 4. С. 367-384.

12. Ильясов Н.Р. Геохимия золота и серебра в месторождениях и рудопроявлениях в одном из рудных полей Малого Кавказа : автореф. дис. ... канд. геол.мин. наук. Баку, 1974. 38 с.

13. Чан Туан Ань, Гаськов И.В., Чан Чонг Хоа, Невалько П.А., Фам Тхи Зунг. Минералого-геохимические особенности и условия образования полиметаллических месторождений структуры Логам СевероВосточного Вьетнама // Геология и геофизика. 2012. T. 55, № 7. C. 817-833.

14. Гейдаров А.С., Эфендиев Г.Х., Лажинина Н.Ф. Редкие элементы руд Мехманинской группы полиметаллических месторождений // Геохимия редких элементов. Баку: Изд-во АН АзССР, 1966. С. 27-38.

15. Ковалев К.Р., Дистанов Э.Г., Аношин Г.Н., Гаськов И.В., Акимџев В.А., Баулина М.В. Золото и серебро в рудах вулканогенных гидротермальных и гидротермально-осадочных колчеданно-полиметаллических месторождений Сибири // Геология и геофизика. 2004. Т. 45, № 10. С. 1171-1185.

16. Волков А.В., Саава Р.Е., Колова Е.Е., Прокофьев В.Ю., Мурашов К.Ю. Аu-Ag эпитермальное месторождение двойное (Чукотка, Россия) // Геология рудных месторождений. 2018. Т. 60, № 6. C. 596-609.

17. Мансуров М.И., Каландаров Б.Г., Керимли У.И., Гусейнов А.И. Распределение золота и сопутствующих рудогенных элементов в золото-медноколчеданных рудах Кызылбулагского месторождения (Малый Кавказ, Азербайджан) // Изв. вузов. Сев.-Кавк. регион. Естеств. науки. 2020. № 3. С. 51-59. Doi 10.18522/1026-237-2020-3-51-59.

18. Баба-заде В.М., Бекташи С.А., Каландаров Б.Г. Серебросодержащие полиметаллические руды азербайджанской части Малого Кавказа // Вестн. Бакинского ун-та. Серия естеств. наук. 1995. № 2. С. 86-93.

19.Гаськов И.В., Владимиров А.Г., Ханчук А.И., Павлова Г.А., Гвоздев В.И. Особенности распределения индия в рудах некоторых полиметаллических и оловосульфидных месторождений Сибири и Дальнего Востока России // Геология рудных месторождений. 2017. Т. 59, № 1. С. 62-74.

20. Геохимия процессов миграций рудных элементов / под ред. Н.И. Хитарова. М.: Наука, 1977. 270 с.

21. Данильченко В.А., Варгунина Н.П., Гордеев С.Г., Орлов Б.Ю. Скрытая свинцово-цинковая минерализация в пределах участка Гаудор Садонского рудного района // Геология и разведка. 2004. № 1. С. 37-42.

22. Добровольская М.Г. Свинцово-цинковое оруденение (рудные формации, минеральные парагенезисы, особенности рудообразования). М.: Наука, 1989. $216 \mathrm{c}$. 